\title{
GAS CHROMATOGRAPHY AND MASS SPECTROMETRY OF THE ETHANOLIC EXTRACT OF NEST MATERIAL OF MUD DAUBER WASP, SCELIPHRON CAEMENTARIUM
}

\author{
SUSHEELA P ${ }^{1 *}$, ROSALINE MARY ${ }^{2}$, RADHA $\mathbf{R}^{3}$ \\ ${ }^{1}$ Department of Zoology, P.S.G.R Krishnammal College for Women, Coimbatore, Tamil Nadu, India. ${ }^{2}$ Department of Zoology, Nirmala College \\ for Women, Red Fields, Coimbatore, Tamil Nadu, India. ${ }^{3}$ Department of Zoology, Sree Ayyappa College for Women, Nagercoil, Tamil Nadu, \\ India. Email: susheelasomu@gmail.com \\ Received: 10 November 2017, Revised and Accepted: 06 April 2018
}

ABSTRACT

Objective: The objective of the present study was to determine the chemical compounds present in the nests of the mud dauber wasp, Sceliphron caementarium.

Methods: Gas chromatography-mass spectrometry analysis of the nest samples was carried out by standard procedures. The resultant compounds were compared with the database of the National Institute Standard and Technology (NIST), WILEY8, FAME.

Results: The results of the gas chromatography-mass spectrometry analysis of the concentrated ethanol extract revealed the presence of chemical compounds such as methylene chloride, 1, 1':3', 1'”-Terphenyl, 5'-Phenyl, Di N Decylsulfone, Eicosanoic acid, 1, 2-Bis (Trimethylsilyl) Benzene, and Androstane-11, 17-Dione, 3-[(Trimethylsilyl) Oxy]-, 17-[0-(Phenylmethyl) 0.

Conclusion: The compounds identified were found to have biological properties such as anti-inflammatory, antibacterial, and antifungal, and further study of these isolated compounds may prove their medicinal importance in future.

Keywords: Gas chromatography-mass spectrometry, Ethanol extract, Sceliphron caementarium.

(C) 2018 The Authors. Published by Innovare Academic Sciences Pvt Ltd. This is an open access article under the CC BY license (http://creativecommons. org/licenses/by/4. 0/) DOI: http://dx.doi.org/10.22159/ajpcr.2018.v11i7.23611

\section{INTRODUCTION}

Certain species of insects during the process of metabolism release chemicals that were used as drugs for treating several diseases due to their therapeutic nature in olden ages [1,2]. The medicines prepared by the folk people involved either directly or indirectly several plants and animal-based products due to their efficacy as potential drugs [3]. Zootherapeutic universality hypothesis states that the usage of animals as medicines in a structured system of medicine has been in prevalence throughout the civilization of humans [4]. Even in the modern culture, it has been observed that animal-based medicines have carved a separate niche for themselves when coming to the practice of magic rituals and healing treatments among people belonging to various religions of indigenous, western, and other societies across the world $[5,6]$.

Insects as their whole body or/and their products such as excrements, corporal secretions, nests, and cocoons have an important role to play in the drug formulations [7]. In African continents, especially among the people of Burkina and Chad, the termite mounds are crushed, mixed with water, and used as a plaster over the fractures. The nests of the mason wasp and mud dauber wasp are applied over the swellings to relieve the pain and also for pain in the spleen region. The nests of these wasps are boiled with water and consumed after removing the pupae or the larvae as they are found serve a number of curing purposes [8]. The traditional insect medicine serves well for treating various ailments such as conjunctivitis, anemia, rheumatics, asthma, malaria, chest pain, chest infection, throat infection, cough, back pain, ulcer, body pain, headache, cold, and burns and for treating wasp bites, bee bites, and other insect bites [9]. Reports that say wasps form an important aspect in the preparation of medicines in ancient Mexico, especially in the South American cultures [10,11]. Even the great historical books of India such as Charak Samhita and Ayurveda have documented the usage of traditional zootherapeutic medicines. About $15-20 \%$ of ayurvedic medicinal composition comprises of the products derived from the animal and its products [12].
Many arthropods (such as bees, scarab larvae, cicada nymphs, mole crickets, wasps, and centipedes) are constantly under the threat of microbial attacks, and to overcome the associated diseases, they incorporate certain antimicrobial compounds into their nests [13]. The insect nests are effectively used by the indigenous people of India for their therapeutic nature like in case of the Kurichchan tribes, who make a paste out of the nests of the wasp belonging to Eumenes species and apply topically over the forehead to treat their headaches, and sometimes, coconut oil and the nests are boiled together before application. The interior of the ant mud hill is effectively used by the Paniyan tribes for treating scabies [14].

Recent advances in science have also led to the green synthesis of nanoparticles using the biomaterials of the arthropods such as cobwebs, silk, and nests [15]. Nanoparticles synthesized from spider cobweb exhibited antimicrobial activity $[16,17]$ and that from the nests of the paper wasps of the genus Polistes showed activities such as thrombolytic, anticoagulant, antifungal, and antibacterial [18].

Based on these aspects on the importance of the novel biomaterials of arthropods as therapeutic agents, the present work was attempted to investigate chemical compounds in ethanolic extracts of the nests of the mud dauber wasp, Sceliphron caementarium by gas chromatographymass spectrometry (GC-MS).

\section{METHODS}

Study area

Fresh nests of the wasp S. caementarium were collected from different parts of Coimbatore, Tamil Nadu. Care was taken not to harm the inhabitants of the nests while scraping off the nest materials with the scalpels. Distilled water was used to wash the nests thoroughly so as to remove the dust and other materials surrounding them. The samples were later air-dried $\left(30 \pm 2^{\circ} \mathrm{C}\right)$, powdered, and stored until extraction in airtight container. 
Preparation of nest extracts

About $10 \mathrm{~g}$ of sample was taken and extracted using $100 \mathrm{~mL}$ of ethanol and Soxhlet apparatus, and later, filtered through Whatmann No.1 filter paper. The extract was dried under reduced pressure (1500 psi) at room temperature, labeled, and stored in small vials at $\times 20^{\circ} \mathrm{C}$.

\section{Analysis of chemical compounds using GC-MS}

A model of Clarus 680 Perkin Elmer Turbo Mass Spectrophotometer fused with silica capillary column $(30.0 \mathrm{~mm} \times 250 \mu \mathrm{m})$ for performing GC-MS analysis. The ionization mode electron impact was at $70 \mathrm{eV}$. Helium was used as carrier gas at a constant flow of $1 \mathrm{ml} / \mathrm{min} .1 .0 \mu \mathrm{L}$ of the sample was injected to GC-MS at a split mode ratio 10:1. The injector temperature was maintained at $260^{\circ} \mathrm{C}$, and the ion-source temperature was $240^{\circ} \mathrm{C}$. Oven temperature maintained initially at $60^{\circ} \mathrm{C}$ for $2 \mathrm{~min}$, ramp $10^{\circ} \mathrm{C} / \mathrm{min}$ to $300^{\circ} \mathrm{C}$, and held for $6 \mathrm{~min}$. The fragments were scanned from 40 to $600 \mathrm{Da}$. 30 min was the total running time of GC-MS. GC-MS National Institute Standard and Technology (2008) is a database having more than 62,000 patterns of spectrum of known components, and this was compared and matched with the unknown spectrums obtained during our study $[18,19]$.

\section{RESULT}

GC-MS analysis is a valuable tool employed in the identification of chemical compounds in a given sample. Separation of the compounds takes place depending on the molecular formula, molecular weight, peak area\% (concentration), and retention time. The constituents include alcohols, long chain hydrocarbons, esters, acids, alkaloids, amino as well as nitrogen compounds. The main focus of the present work was toward the identification of the chemical compounds in the ethanol nest extract of $S$. caementarium by employing GCMS, and a total of eight compounds were identified (Fig. 1). As far as the literature survey is concerned, and to the best of our knowledge, no work has been previously reported with this regard. Compounds such as methylene chloride (28.72\%, 3.61\%), Eicosanoic acid (2.20\%), Sulfurous Acid, Pentadecyl 2-Propyl Ester (2.82\%), 1, 1':3', 1'-Terphenyl, 5'-Phenyl (43.35\%), Di-N-Decylsulfone (14.33\%),1,2-Bis(Trimethylsilyl) Benzene (2.64\%), and Androstane11,17-Dione,3-[(Trimethylsilyl) 0xy]-, 17-[0- (Phenylmethyl) 0 $(2.30 \%)$ were identified. Six of them are reported to be important due to their biological activity (Table 1). The biological activities of isolated compounds are based on Dr. Duke's Phytochemical and Ethnobotanical Databases by Dr. Jim Duke of the Agricultural Research Service/USDA [20]

\section{DISCUSSION}

For centuries, natural products from both plants and animals have been considered as therapeutic agents and the reason behind this fact could be the presence of chemical compounds that make them more efficient in curing a variety of diseases. The components identified in the nest of $S$. caementarium have also been previously isolated from plants, and their pharmaceutical efficiency has been demonstrated in a number of studies.

1, 1': 3', 1'-Terphenyl, 5'-Phenyl which constitutes $43 \%$ is a hydrocarbon and is anti-inflammatory in function [21]. Terphenyl derivatives have been isolated from microbes and mushrooms [22] and are considered valuable due to the biological aspects such as being antithrombotic, anti-inflammatory, anticoagulants, immune suppressants, and also cytotoxic activities [23]. Di-N-Decylsulfone contributes to $14 \%$ in the tested extract and is an ester. This compound was also isolated from the roots of the plant Spatholobus purpureus and its presence exhibited several activities such as antihelmintic, antioxidant, antifungal, and antimicrobial [24].

Sulfurous acid and Pentadecyl 2-Propyl Ester make up to around 3\% of the extract and are volatile compounds that show antioxidant, antimicrobial, and anti-inflammatory activity [25-27]. The phenolic

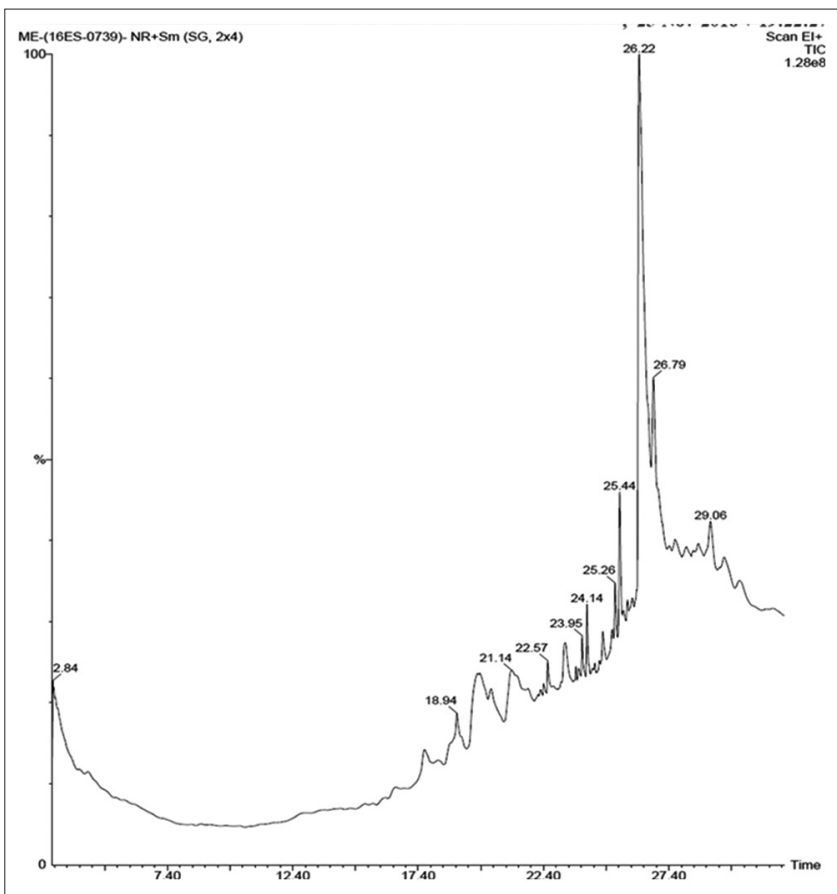

Fig. 1: Gas chromatography and mass spectrometry chromatogram of the ethanol extract of nest of Sceliphron caementarium

Table 1: Activity of the chemical compounds identified in the ethanol extract of the nest of S. caementarium

\begin{tabular}{|c|c|c|c|c|c|c|c|}
\hline S. No & Compound name & $\begin{array}{l}\% \text { of Peak } \\
\text { Area }\end{array}$ & RT & MF & MW & $\begin{array}{l}\text { Compound } \\
\text { nature }\end{array}$ & Pharmacological activity \\
\hline 1. & Methylene Chloride & 28.72 & 2.86 & $\mathrm{CH}_{2} \mathrm{C}_{12}$ & 84 & Hydrocarbon & No activity reported \\
\hline 2. & Methylene Chloride & 3.61 & 3.94 & $\mathrm{CH}_{2} \mathrm{C}_{12}$ & 84 & Hydrocarbon & No activity reported \\
\hline 3. & Eicosanoic Acid & 2.20 & 19.74 & $\mathrm{C}_{20} \mathrm{H}_{40}^{2} \mathrm{O}_{2}$ & 312 & Fatty acids & Anti-inflammatory Antioxidant \\
\hline 4. & $\begin{array}{l}\text { Sulfurous Acid, Pentadecyl } \\
\text { 2-Propyl Ester }\end{array}$ & 2.82 & 25.44 & $\mathrm{C}_{18}^{20} \mathrm{H}_{38}^{40} \mathrm{O}_{3}^{2} \mathrm{~S}$ & 334 & Esters & $\begin{array}{l}\text { Antioxidant, Antimicrobial, } \\
\text { Anti-inflammatory }\end{array}$ \\
\hline 5. & $\begin{array}{l}\text { 1,1':3',1"-Terphenyl, } \\
\text { 5'-Phenyl }\end{array}$ & 43.35 & 26.21 & $\mathrm{C}_{24} \mathrm{H}_{18} \mathrm{O}_{3} \mathrm{~S}$ & 306 & Hydrocarbon & Anti-inflammatory \\
\hline 6. & Di-N-Decylsulfone & 14.33 & 26.78 & $\mathrm{C}_{20} \mathrm{H}_{4} \mathrm{O}_{2} \mathrm{~S}$ & 346 & Ester & Antifungal, Antimicrobial, Antihelmintic \\
\hline 7. & $\begin{array}{l}\text { 1,2-Bis (Trimethylsilyl) } \\
\text { Benzene }\end{array}$ & 2.64 & 29.06 & $\mathrm{C}_{12}^{20} \mathrm{H}_{22}^{42} \mathrm{Si}_{2}^{2}$ & 222 & Phenol & Antibacterial Antimicrobial, Antioxidant \\
\hline 8. & $\begin{array}{l}\text { Androstane-11,17-Dione, } \\
\text { 3-[(Trimethylsilyl) Oxy]-, } \\
\text { 17-[0-(Phenylmethyl) 0 }\end{array}$ & 2.30 & 29.61 & $\mathrm{C}_{29} \mathrm{H}_{43} \mathrm{O}_{3} \mathrm{NSi}$ & 481 & Steroid & Antimicrobial, Anti-inflammatory \\
\hline
\end{tabular}

*Source: Dr. Duke's phytochemical and ethnobotanical databases. RT: Retention time, MF: Molecular formula, MW: Molecular weight, S. caementarium: Sceliphron caementarium 
compound 1, 2-Bis(Trimethylsilyl) Benzene (2.6\%) isolated during this study is reported to contribute to the free radical scavenging property by absorbing them and acting as metal chelators [28]. Many plants produce phenolics as secondary metabolites which hold responsible for their antioxidant properties. The presence of sterol, terpenoids, and phenolics and in case of $C$. rotundus holds responsible for its antioxidant and anticancer activity [29]. Androstane-11, 17-Dione, 3-[(Trimethylsilyl) 0xy]-, 17-[0-(Phenylmethyl) 0 contributes to $2.3 \%$, is steroid, and has been previously isolated from plants. The Androstane steroid 3-[(trimethylsilyl) oxy]-17[0-(phenylmethyl) oxime]- $(3 \alpha, 5 \alpha)$ - androstane-11, 17-dione has been reported as a unique constituent in the plant Anacardium occidentale [30]. These steroids have been reported to have capacity to lessen anxiety, seizures, premenstrual disorders, mood disorders, depression, and stress, for treating memory and neural system damage [31,32]. Although the Eicosanoic acid shows only $2 \%$ of the nest extract, it possesses anti-inflammatory and hepatoprotective properties [33]. These chemicals also show high affinity for scavenging reactive free radicals that can cause tissue damage and cell death [34]. Eicosanoic acid isolated along with n-tetracosanol and arjunolic acid from Combretum microphyllum (Combretaceae) leaf extracts showed antimutagenic activity [35].

\section{CONCLUSION}

This preliminary study has provided a platform to study the chemical compounds present in the nest materials of $S$. caementarium, but further research has to be carried by isolation and purification of these compounds so that they can be effectively employed for drug formulations in future.

\section{REFERENCES}

1. Dossey AT. Insects and their chemical weaponry: New potential for drug discovery. Nat Prod Rep 2010;27:1737-57.

2. Gifte DK. Pharmaka aus Insekten-ihre Herkunft, Wirkung und ökologische edeutung. Entomol Heute 2007;19:3-28.

3. Strobel G, Daisy B. Bioprospecting for microbial endophytes and their natural products. Microb Mol Biol Rev 2003;67:491-2.

4. Marques JG. Fauna medicinal: Recurso do ambiente ou ameaça à biodiversidade? Mutum 1997;1:1-4.

5. Angeletti LR, Agrimi C, Curia D, Mariani-Costantini R. Healing rituals and sacred serpents. Lancet 1992;340:23-225.

6. Rosner F. Pigeons as a remedy (segulah) for jaundice. New York State J Medicine 1992;92:189-92.

7. Costa Neto PL, Canuto SA. Management with Quality. Blucher, São Paulo: Blucher,; 2010. p. 150-1.

8. Van Huis A. Medical and stimulating properties ascribed to arthropods and their products in sub-Saharan Africa. In: Motte-Florac E, Thomas JM, editors. Les Insectes Dans la Tradition Orale-insects in Oral Literature and Traditions. Paris: Peeters Selat (Ethnosciences); 2002. p. 367-82.

9. Costa Neto EM. Traditional Use and Sale of Animals as Medicines in Feira de Santana City, Bahia, Brazil. Netherlands: Indigenous Knowledge and Development Monitor; 1999.

10. Posey DA. Topics and issues in ethnoentomology with some suggestions for the development of hypothesis generation and testing in ethnobiology. J Ethnobiol 1986;6:99-120.

11. Ramos-Elorduy de Conconi J, Moreno JM. The utilization of insects in the empherical medicine of ancient Mexicans. J Ethnobiol 1988;8:195-202.

12. Unnikrishnan PM. Animals in Ayurveda. J Amruth 1998:1:1-15.

13. Beattie AJ, Turnbull CL, Hough T. Antibiotics production: A possible function for the metapleural glands of ants (Hymenoptera: Formicidae),
Annals Entomol Soc Am 1986;79:448-50.

14. Wilsanand V. Preema V. Rajitha P. Therapeutics of insects and insect products in South Indian traditional medicine. Indian J Tradit Knowl 2007;7:563-8.

15. Aramwit P, Siritienthong T, Srichana T, Ratanavaraporn J. Accelerated healing of full-thickness wounds by genipin-crosslinked silk sericin/ PVA scaffolds. Cells Tissues Organs 2013;197:224-38.

16. Lateef A, Ojo SA, Azeez MA, Asafa TB, Yekeen TA, Akinboro A, et al. Cobweb as novel biomaterial for the green and eco-friendly synthesis of silver nanoparticles. Appl Nanosci 2015d. DOI: 10.1007/s13204-0150492-9.

17. Lateef A, Akande MA, Ojo SA, Folarin BI, Gueguim-Kana EB, Beukes LS. Paper wasp nest-mediated biosynthesis of silver nanoparticles for antimicrobial, catalytic, anti-coagulant and thrombolytic applications. 3 Biotech 2016;6:140.

18. Stein SE. National Institute of Standards and Technology (NIST) Mass Spectral Database and Software, Version 3.02, USA; 1990.

19. Kirk H, Sawyer R. Frait Pearson. Chemical Analysis of Food. $8^{\text {th }}$ ed. Edinburgh: Longman Scientific and Technical; 1998. p. 211-2.

20. Dr. Duke's Phytochemical and Ethnobotanical Databases. Available from: http://www.ars-grin.gov/duke.

21. Sannigrahi S, Mazumder UK, Mishra SL. Terpenoids of methanol extract of Clerodendrum infortunatum exhibit anticancer activity against Ehrlich's Ascites Carcinoma in mice. Pharm Biol 2012;50:304-9.

22. Gill M, Steglich W. Pigments of fungi (Macromycetes). Fortschr Chem Org Naturst 1987;51:1-317.

23. Deshmukh OS. GC-MS analysis of root acetone extracts of Spatholobus purpureus- a high ethno-veterinary medicinal value plant. Int J Curr Res 2015;7:23039-42.

24. Azulwork HG, Siddiqui S, Arshad MD, Jafri A, Malik T. The phytochemical investigation, GC-MS profile and antimicrobial activity of a medicinal plant Ruta graveolens L. from ethiopia. Int J Pharm Pharm Sci 2017;9:29-34

25. Safayhi H, Sailer ER. Anti-inflammatory actions of pentacyclic triterpenes. Planta Med 1997;63:487-93.

26. Liu JK. Natural terphenyls: Developments since 1877. Chem Rev 2006; 106:2209-23

27. Astrue D. Modern Arene Chemistry. Weinheim, Germany: Wiley-VCH; 2002.

28. Nandi S, Vracko M, Bagchi MC. Anticancer activity of selected phenolic compounds: QSAR studies using ridge regression and neural networks. Chem Biol Drug Des 2007:70:424-36.

29. Hema N, Avadhani R, Ravishankar B, Anupama N. A comparative analysis of antioxidant potentials of aqueous and ethanolic extracts of Cyperus rotundus (L.). Asian J Biomed Pharm Sci 2013;3:7-11.

30. Fadeyi OE, Olatunji GA, Ogundele VA. Isolation and characterization of the chemical constituents of Anacardium occidentale Cracked Bark. Nat Prod Chem Res 2015;3:192.

31. Eziuzo OS. Chukwu Amarauche studies on Sida acuta hydrogel i: Processing and physicochemical properties of the derived hydrogel obtained from south east nigeria. Int J Pharm Pharm Sci 2017;9:5-11.

32. Runyon SP, Rogawski M, Cook E, Kepler J, Navarro H. Androstane and Pregnane Steroids With Potent Allosteric Gaba Receptor Chloride Ionophore Modulating Properties. United States Patent Application; 2014. p. 20140094619

33. Patil U, Deshmukh O. GC-MS Analysis of phytochemicals in the aqueous extract of Cyclea peltata.(Lam) Hook. f. and Thomson. Int J Sci Res 2016:4:350-1.

34. Lingli MU, Junping KO, Zhu D, Yu B. Comparison of neuroprotective effects of flavonoids, terpenoids, and their combinations from ginkgo bilobaon ischemia-reperfusion-injured mice. Pharm Biol 2007;45:728-33.

35. Makhafola TJ, Elgorashi EE, McGaw LJ, Awouafack DA, Verschaeve L, et al. Isolation and characterization of the compounds responsible for the antimutagenic activity of Combretum microphyllum (Combretaceae) leaf extracts. BMC Complement Altern Med 2017;17:446 